\title{
Hylocomium Splendensas a Bio-Indicator for Heavy Metal and Hydrocarbons in Port Harcourt
}

\author{
Fabian U, Stevens AO and Nnabuk $\mathrm{OE}^{*}$ \\ Department of Chemistry, Michael Okpara University of Agriculture, Nigeria
}

Submission: September 27, 2017; Published: October 12, 2017

*Corresponding author: Nnabuk Okon Eddy, Department of Chemistry, Michael Okpara University of Agriculture, Umudike, Abia State, Nigeria, Email: nabukeddy@yahoo.com

\begin{abstract}
Heavy metal and hydrocarbon concentrations in air within some industrial locations within Port Harcourt were investigated using moss plant, Hylocomium Spiendens obtained from the respective locations. Twenty five locations were identified based on various industrial activities. Concentrations of $\mathrm{Al}, \mathrm{Mg}, \mathrm{Na}, \mathrm{Pb}, \mathrm{Hg}, \mathrm{Cr}, \mathrm{V}, \mathrm{Cu}, \mathrm{Zn}, \mathrm{NI}$ and $\mathrm{Cu}$ ions in moss samples collected from twenty five different locations within Port Harcourt were fairly below the permissible limit indicating that air in the city is relatively unpolluted with respect to heavy metals ions. Hydrocarbon streams in the study area reveals the presence of n-C10 to n-C34, which are evidence of the presence of UCM, GRO and DRO These suggest that past and recent hydrocarbon contaminations by crude oil and by-product of crude oil abound in the city.
\end{abstract}

Keywords: Heavy metals and hydrocarbon pollution; Biomonitoring; Hylocomium Spiendens

\section{Introduction}

Global industrialization has opens the atmosphere to pollution through the trapping of numerous gases and particles arising from industrial processes. The degree and extent of environmental changes over the last decades has given a new urgency and relevance to the detection and understanding of environmental change, due to human activities, which have altered global biogeochemical cycling of heavy metals and other pollutants. Pollution of the environment (except air) has been extensively studied indicating that there is serious need to enlarge research bandwidth to air pollution. Pollution of the air basically arises from contamination from gases and particulates (mostly metals) [1]. Air pollution due to gases can be effectively monitored through measurement (using respective gas sensitive sensor or other instrument) but pollution due to particulates presents some challenges in monitoring using probes. However, one of the most effective methods involves the use of some plants (mostly mosses) as bio-indicators (i.e. biomonitoring) [2,3].

Biomonitoring with mosses is based on the fact that mosses obtained most of their nutrients directly from wet and dry deposition [4]. Therefore, they clearly reflect the atmospheric deposition and are thus suited as pollution indicator, especially for heavy metal pollution over a period of time [5,6]. Mosses are also suitable bio-indicators for elevated Sulphurdioxide (SO2) concentration and their contaminants emitted to the atmosphere from natural and anthropogenic sources $[4,7,8]$.
Some bio-indicators that have been found effective for biomonitoring include, Hypnum cupressiforme Hylocomium splendens and Pleurozium schreberi [9]. Other studies on the use of bio-indicators have also been documented [10-18].

Numerous studies have been published on the use of mosses as bio-indicators. Some of the reported work include the use of Sphagnum girgensohnii Russow for bio-monitoring of metals [19,20]. Mendill et al. [21] also used 14 different lichen and moss samples to study heavy metal pollution in Sivas-Tokat motorway (5-25 $\mathrm{m}$ ) and recorded the following concentrations $468.1 \mathrm{~g} / \mathrm{g}(\mathrm{Fe}), 270.5 \mathrm{~g} / \mathrm{g}(\mathrm{Mn}), 67.6 \mathrm{~g} / \mathrm{g}(\mathrm{Zn}), 53.3 \mathrm{~g} / \mathrm{g} \mathrm{(Pb)}$, $79.6 \mathrm{~g} / \mathrm{g}(\mathrm{Ni}), 33.9 \mathrm{~g} / \mathrm{g}(\mathrm{Cr}), 29.6 \mathrm{~g} / \mathrm{g} \mathrm{(Cu})$ and $5.7 \mathrm{~g} / \mathrm{g}(\mathrm{Cd})$ for mosses, $455.5 \mathrm{~g} / \mathrm{g}(\mathrm{Fe}), 170.5 \mathrm{~g} / \mathrm{g}(\mathrm{Mn}), 77.6 \mathrm{~g} / \mathrm{g} \mathrm{(Zn),} 6.5 \mathrm{~g} / \mathrm{g}$ (Pb), $10.1 \mathrm{~g} / \mathrm{g}(\mathrm{Ni}), 3.8 \mathrm{~g} / \mathrm{g}(\mathrm{Cr}), 25.6 \mathrm{~g} / \mathrm{g}(\mathrm{Cu})$ and $1.5 \mathrm{~g} / \mathrm{g}(\mathrm{Cd})$ $\mathrm{g} / \mathrm{g}$ for lichens. Basile et al. [22] conducted a bio-monitoring project using the moss, Scorpiurum circinatum to evaluate the deposition and biological effects of heavy metals in the area of Acerra (Naples, S Italy), one of the vertices of the sadly called "Italian triangle of death" owing to the dramatic increase in tumors. The results they obtained clearly indicated that the study area is heavily polluted by heavy metals, large proportion of which is likely present in the atmosphere in particulate form. Similarly, In their study, Bargagli et al. [23] use samples of the moss, Hypnum cupressiforme and the epiphytic lichen Parmelia, caperata, in an area (Colline Metallifere, central Italy) intensively exploited in the past for metals $(\mathrm{Cu}, \mathrm{Fe}, \mathrm{Pb}, \mathrm{Zn})$. They found that 
Patterns of bioaccumulation of elements throughout the study area were quite similar for widespread pollutants such as $\mathrm{S}, \mathrm{B}$, As, $\mathrm{Zn}, \mathrm{Cr}$ and $\mathrm{Ni}$, but the lichen and the moss showed different distribution patterns of $\mathrm{Hg}, \mathrm{Cd}$ and other elements subject to long-range atmospheric transport. Their results were attributed to differences in the morphology and eco-physiology of mosses and lichens and indicate that these organisms cannot be used interchangeably as biomonitors of metals in areas with mineral deposits.

Figueira et al. [24] conducted a bio-monitoring survey in Portugal using the moss species (Hypnum cupressiforme Hedw. and Scelopodium touretii (Brid L Kock). The results obtained indicated excellent correlation between heavy metal in the air and in the soil within the studied area. In Nigeria, literature is scanty on the use of bio-indicator to monitor air pollution. Therefore, the present study is aimed at investigating the extent of pollution of the air in Port Harcourt by heavy metal and hydrocarbon using the moss, Hylocomium splendens. Port Harcourt is one of the most industrial and commercial cities in Nigeria. Major industrial activities in the city are those associated with oil exploitation and associated activities.

\section{Materials and methods}

Appendix 1: Sampling locations in Port Harcourt and associated industrial activities.

\begin{tabular}{|c|c|c|}
\hline Code & $\begin{array}{l}\text { Location } \\
\text { Name }\end{array}$ & Characteristic Features \\
\hline F1 & $\begin{array}{l}\text { Eleme } \\
\text { Refinery }\end{array}$ & $\begin{array}{l}\text { Port Harcourt Refinery Company (PHRC)- } \\
\text { Offices/ Maintenance Buildings }\end{array}$ \\
\hline $\mathrm{F} 2$ & Eleme Town & Motor Park, residential areas, churches \\
\hline F3 & Rumuokwasi & Residential quarters, Car park, Hospitals \\
\hline $\mathrm{F} 4$ & Rumoula & Business area, Car park, Churches \\
\hline F5 & Rumuchwula & Motor park, Filling station, Residential area \\
\hline F6 & Onne & Trailer park, Business area \\
\hline F7 & Elekohia & Industries, Deserted area \\
\hline F8 & Transamadi & Industries / Business area \\
\hline F10 & Oromenin & Bus stop, Residential quarter \\
\hline F11 & Leventis & Workshop, Motor park, Abandon building \\
\hline F12 & Railway & Deserted area, Bus stop \\
\hline F13 & Diobu & Residential area, Bus Stop, Market places. \\
\hline F14 & UST & $\begin{array}{c}\text { Student hostels, academic area and } \\
\text { Administrative block }\end{array}$ \\
\hline F15 & Air force base & $\begin{array}{c}\text { Business area, Churches, Bus stop/ } \\
\text { Residential area }\end{array}$ \\
\hline F16 & $\begin{array}{l}\text { East/West } \\
\text { Road }\end{array}$ & $\begin{array}{c}\text { Manufacturing industries, Market places, } \\
\text { residential quarter }\end{array}$ \\
\hline F17 & Main Town & $\begin{array}{c}\text { Block industries, bus stop, residential/ } \\
\text { business premises }\end{array}$ \\
\hline
\end{tabular}

The moss samples were collected in Port Harcourt in the locations shown in Appendix 1. The locations were chosen because there are several industrial activities within them. Port Harcourt lies at latitude $4 * 45 \mathrm{~N} 7^{*} 00 \mathrm{E}$ longitude $4 * 75 \mathrm{~N} 7^{*} \mathrm{E}$.
Map of the study is shown in Figure 1. Samples were collected in triplicate from each sampling stations.

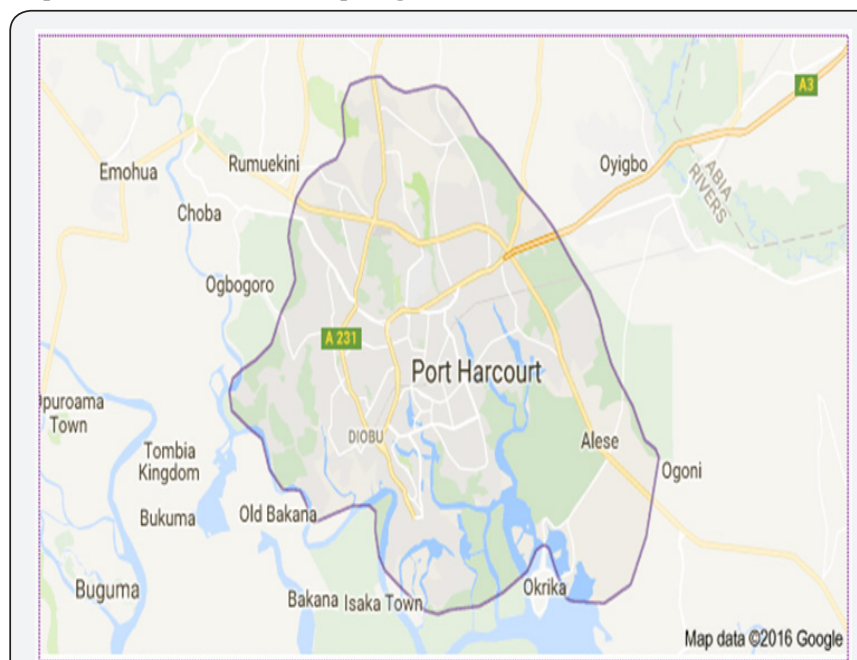

Figure 1: Map of the study area.

\section{Chemical analysis}

Determination of heavy metal: Moss specimens collected from the fields were dried at $85^{\circ} \mathrm{C} .1 \mathrm{~g}$ of each sample was added to a $50 \mathrm{ml}$ beaker. $1.5 \mathrm{ml}$ of concentrated $\mathrm{HNO}_{3}$ was added and allowed to stand for 24 hours. After 24 hours, the sample was heated for 8 hours between the temperature ranges of $50-60{ }^{\circ} \mathrm{C}$. After cooling, $4 \mathrm{ml}$ of $\mathrm{HClO}_{4}$ was added in each sample, and then heated for 4 hours at $100-110{ }^{\circ} \mathrm{C}$. It was again heated up to 190 $200{ }^{\circ} \mathrm{C}$. The precipitate at the bottom flask was cooled; $10 \mathrm{ml}$ of concentrated $\mathrm{HCl}$ and $30 \mathrm{ml}$ of pure water were added. Then it was again heated at $90-95^{\circ} \mathrm{C}$ and the compounds were dissolved in 2-3 hours. The solution was filtered using black filter paper and poured into Pyrex glass ware. Distillated water was added up to the marked level. The heavy metal ion determination in the specimens solution was determined by using atomic absorption spectrometer

GC-MS analysis: A Hewlett-Packard 5800 series II gas chromatograph equipped with a Hewlett Packackard 5971 Mass selective detector (GC-MSD) was used to analyze extracts. After split less injection, compounds were separated with a 30-m J and W scientific DB-XLB fused silica capillary column. The oven was programmed to start at $70^{\circ} \mathrm{C}$ for 15 minute, ramped to $320^{\circ} \mathrm{C}$ at $10{ }^{\circ} \mathrm{C}$ per minute and held for 10 minutes. Data were collected with Hewlett-packard Chem Station software. The MSD was operated in the SIM mode at a scan mode (m/z 50 to 550).

\section{Results and Discussions}

\section{Metal ions in moss}

Table 1 presents results obtained for the concentrations of $\mathrm{Al}, \mathrm{Mg}, \mathrm{Na}, \mathrm{Pb}, \mathrm{Hg}, \mathrm{Cr}, \mathrm{V}, \mathrm{Cu}, \mathrm{Zn}, \mathrm{NI}$ and $\mathrm{Cu}$ ions from mosses in Port Harcourt. From the results obtained, it is evident that the concentrations of aluminum ranged from 60.12ppm (at F-13: Diobu) to 116ppm (Dockyard Creek). Mean concentrations of aluminum in the study area was $84.87 \mathrm{ppm}$ respectively while 
the variability of the data (i.e. standard deviation) was 16.38 . The relatively high concentration of aluminum ions in the study area can be attributed to the high level of industrial activities in these zones. Bunchnea \& Buchnea [25] have identified corrosion of air conditioner as one of the major consequences of aluminum air pollution. They found that hydrated aluminum oxide $\left(\mathrm{Al}_{2} \mathrm{O}_{3}\right.$. $\mathrm{H}_{2} \mathrm{O}$ and $\left.\mathrm{Al}_{2} \mathrm{O}_{3} \cdot \mathrm{H}_{2} \mathrm{O}\right)$, carbonated aluminum oxide $\left(\mathrm{Al}_{2} \mathrm{O}_{3} \cdot \mathrm{CO}_{2}\right)$ contribute to air pollution as the products of corrosion of air conditioners. In cold room, at 3 to $6{ }^{\circ} \mathrm{C}$, these pollutants precipitate from the air coating all surfaces in the room with a film of grey dust. In air conditioned rooms at normal temperature of 20 to $25{ }^{\circ} \mathrm{C}$, this aluminum based film was not evidence. Aluminum is a widely used metal because of its high thermal and electrical conductivity, its high weight and its resistance to corrosion. The metal has high density, high melting point and great insolubility [26].

Table 1: Result of some metal ions obtained in moss samples analysis in Port Harcourt.

\begin{tabular}{|c|c|c|c|c|c|c|c|c|c|c|c|c|}
\hline Code & Location & $\begin{array}{c}\text { Al } \\
(\mathrm{ppm})\end{array}$ & $\begin{array}{c}\mathrm{Mg} \\
(\mathrm{ppm})\end{array}$ & $\begin{array}{c}\mathrm{Na} \\
(\mathrm{ppm})\end{array}$ & $\begin{array}{c}\mathrm{Pb} \\
(\mathrm{ppm})\end{array}$ & $\begin{array}{c}\mathrm{Hg} \\
(\mathrm{ppm})\end{array}$ & $\begin{array}{c}\mathrm{Cr} \\
(\mathrm{ppm})\end{array}$ & $\begin{array}{c}\mathrm{V} \\
(\mathrm{ppm})\end{array}$ & $\begin{array}{c}\mathrm{Cu} \\
(\mathrm{ppm})\end{array}$ & $\begin{array}{c}\text { Zn. } \\
(\mathrm{ppm})\end{array}$ & $\begin{array}{c}\mathrm{Ni} \\
\text { (ppm) }\end{array}$ & $\begin{array}{c}\mathrm{Fe} \\
(\mathrm{ppm})\end{array}$ \\
\hline F-1 & $\begin{array}{l}\text { PHRC Eleme } \\
\text { Refinery Depot }\end{array}$ & 69.42 & 200.43 & 230.43 & 18.88 & 0.04 & 8.35 & 4.02 & 8.11 & 18.76 & 2.86 & 5.21 \\
\hline $\mathrm{F}-2$ & Eleme Town & 79.32 & 232.51 & 234.421 & 18.88 & 0.04 & 8.33 & 4 & 8.15 & 18.92 & 2.87 & 5.21 \\
\hline F-3 & Rumuokwosi & 94.24 & 228.23 & 285.26 & 15.36 & 0.05 & 8.35 & 3.6 & 9.2 & 20.24 & 2.66 & 6.22 \\
\hline $\mathrm{F}-4$ & Rumuola & 80.21 & 245.53 & 225.37 & 10.12 & 0.03 & 1.37 & 1.46 & 6.87 & 20 & 1.1 & 5.2 \\
\hline F-5 & Rumuihwuta & 69.85 & 220.44 & 265.24 & 10.13 & 0.03 & 1.36 & 2.2 & 7.85 & 18.4 & 1.89 & 5.21 \\
\hline F-6 & Onne & 70.23 & 203.41 & 220.42 & 18.35 & 0.06 & 8.96 & 1.26 & 7.65 & 16.15 & 1.52 & 4.32 \\
\hline F-7 & Elikohia & 89.42 & 256.52 & 322.98 & 9.42 & $<0.02$ & 1.98 & 1.67 & 5.76 & 15.68 & 1.35 & 4.56 \\
\hline F-8 & Transamadi & 68.54 & 252.62 & 324.12 & 18.84 & 0.02 & 2.12 & 1.98 & 8.34 & 16.87 & 1.78 & 4.84 \\
\hline F-9 & Rainbow Town & 97.26 & 232.62 & 318.12 & 18.83 & 0.03 & 2.5 & 3.84 & 8.74 & 20.22 & 1.94 & 5.9 \\
\hline F-10 & Oromenin & 95.54 & 216.42 & 295.16 & 15.54 & 0.03 & 2.16 & 3.53 & 9.2 & 22.15 & 2.35 & 5.78 \\
\hline F-11 & $\begin{array}{c}\text { Leventis Motor } \\
\text { Park }\end{array}$ & 76.43 & 228.02 & 284.26 & 16.35 & 0.02 & 2.2 & 3.2 & 9.45 & 18.24 & 2.44 & 6.54 \\
\hline F-12 & Railway & 79.22 & 125.02 & 236.67 & 15.26 & 0.02 & 2.36 & 2.21 & 5.67 & 15.21 & 1.22 & 4.2 \\
\hline $\mathrm{F}-13$ & Diobu & 60.12 & 230.42 & 347.11 & 10.12 & $<0.02$ & 2.11 & 1.47 & 6.35 & 14.62 & 1.35 & 4.18 \\
\hline F-14 & U.S. T & 88.24 & 219.02 & 347.86 & 10.2 & $<0.02$ & 1.86 & 2.18 & 6.34 & 14.68 & 1.26 & 4.18 \\
\hline F-15 & Air Force & 85.43 & 22.05 & 348.34 & 15.43 & 0.05 & 8.34 & 6.98 & 8.67 & 20.6 & 7.89 & 7.34 \\
\hline F-16 & East/West Road & 95.65 & 245.05 & 256.48 & 15.65 & 0.05 & 8.48 & 6.94 & 8.54 & 24.54 & 7.95 & 7.45 \\
\hline F-17 & Industry Road & 106.26 & 253.04 & 321.24 & 16.26 & 0.04 & 8.24 & 7.45 & 8.62 & 26.43 & 8.24 & 7.23 \\
\hline F-18 & Main Township & 99.87 & 265.04 & 344.67 & 14.87 & 0.04 & 7.67 & 7.53 & 9.24 & 26.54 & 8.43 & 7.15 \\
\hline F-19 & Calabari Creek & 114.84 & 262.02 & 357.42 & 9.25 & $<0.02$ & 1.86 & 7.64 & 9.22 & 28.85 & 8.54 & 6.89 \\
\hline F-20 & $\begin{array}{l}\text { HaroldWilson } \\
\text { Drive }\end{array}$ & 104.45 & 283.02 & 363.35 & 14.45 & 0.02 & 7.35 & 7.54 & 9.12 & 26.45 & 7.87 & 6.76 \\
\hline $\mathrm{F}-21$ & Dockyard Creek & 116.65 & 234.05 & 328.24 & 13.45 & 0.02 & 6.26 & 8.56 & 9.87 & 38.2 & 7.9 & 7.85 \\
\hline $\mathrm{F}-22$ & Oginigba & 79.56 & 235.22 & 244.18 & 9.56 & $<0.02$ & 2.18 & 1.54 & 5.63 & 14.4 & 1.47 & 4.24 \\
\hline $\mathrm{F}-23$ & Mile 3 Park & 60.32 & 230.42 & 367.11 & 16.35 & 0.02 & 2.34 & 0.47 & 6.35 & 14.62 & 1.25 & 4.13 \\
\hline F-24 & Rumuomasi & 80.38 & 22.06 & 338.38 & 14.25 & 0.03 & 2.26 & 2.15 & 5.62 & 11.23 & 6.26 & 6.15 \\
\hline $\mathrm{F}-25$ & Akpakim House & 60.35 & 23.07 & 232.6 & 16.65 & 0.05 & 8.24 & 2.05 & 4.28 & 12.26 & 5.2 & 5.26 \\
\hline
\end{tabular}

Measured concentrations of magnesium in the studied areas ranged from $22.05 \mathrm{ppm}$ (at F24: Rumuomasi) to 283ppm (at F20: Harold Wilson drive) while the mean concentration and standard deviation were 206.65ppm and 75.28. Magnesium ion has not been significantly implicated as an environmental pollutant. However, it is found to be useful in the environment. According to National atmospheric inventory report, base cautions such as magnesium are important in the environment because deposition has an impact upon surface $\mathrm{pH}$, causing an increase in alkalinity, thereby buffering or neutralizing the effects of acidity generated by sulphur and nitrogen.
Sodium concentrations in the study area ranged from 225.70ppm (F4: at Rumuola) to 357.42ppm (F19: at Calabari Creek) with mean concentration and standard deviation of 297.58 ppm and 50.46 respectively. Environmental pollution due to sodium ion is not significant because sodium is one of the major elements that are needed by the body. However, since it is a highly reactive ion, it can reacts with toxic anions and create pollution problem.

Concentrations of lead ion in moss samples ranged from 9.25ppm (at F19: Calabari) to 18.88 (at F1: PHRC and F2: Eleme). 
Mean concentration and standard deviation were 14.50. Major sources of lead are mining and metal manufacturing, waste incinerators; battery recycling; the production of lead fishing sinkers; cement, plaster and concrete manufacturing; ceramic products such as garden pots; iron and steel; petroleum and coal products; paper, glass and metal products; motor vehicles and their parts; wood products; and yarn and fabric for making clothes and curtains. High concentration of lead in the study area reflects the level of industrial activities in Port Harcourt. Lead is a health hazard. It is stored in bones and teeth, and may damage parts of the body, including liver, kidneys and brain. Exposure to lead can affect the health of children, unborn babies and adults. Therefore, there is need to put measures in place toward the control of lead.

Concentration of mercury ions in the studied area was found to range from<0.02 ppm (at F7: Elikohia, F13: Diobu, F14: UST, F19: Calabari and F22: Oginigba) to $0.06 \mathrm{ppm}$ (at F6: One). Corresponding mean and standard deviation were $0.0316 \pm 0.0128$. Global current levels of mercury in outdoor air, except for regional "hot spots", are typically in the order of $0.005-0.010 \mu \mathrm{g} / \mathrm{m}^{3}$ (i.e. $0.005 \times 10^{-3}$ to $0.010 \times 10^{-3} \mathrm{ppm}$ ) Therefore, the mercury level in air within the study locations does not constitute air pollution. The exposure to mercury from outdoor air at these air levels is not expected to have direct effects on human health.

Concentrations of chromium ions in samples of moss obtained from Port Harcourt ion concentrations ranged from 1.36 (at F5: Rumuihwuta) to $8.96 \mathrm{ppm}$ (at F6: Onne). Mean concentration and standard deviation were 4.3572 \pm 3.1241 . According to the Toxics Release Inventory, in 1997, the estimated releases of chromium were 706,204 pounds to the air from 3,391 large processing facilities which accounted for about $2.2 \%$ of total environmental releases. Cr (III) and Cr (VI) are released to the environment primarily from stationary point sources (facilities that are identified individually by name and location) resulting from human activities. Cr (III) in the air does not undergo any reaction. Cr (VI) in the air eventually reacts with dust particles or other pollutants to form Cr (III). However, the exact nature of such atmospheric reactions has not been studied extensively [EPA 1998]. Several regulatory bodies have set standards for the limit of chromium ion concentration in the air. These include American Conference of Governmental Industrial Hygienists $\left(1 \mu \mathrm{g} / \mathrm{m}^{3}\right)$, National Institute for Occupational Safety and Health $\left(10 \mu \mathrm{g} / \mathrm{m}^{3}\right)$ and Occupational Safety and Health Administration $\left(5 \mu \mathrm{g} / \mathrm{m}^{3}\right)$. This implies that the tolerance limit ranged from 1 to $10 \mu \mathrm{g} / \mathrm{m}^{3}$ ). Therefore, chromium ions do not constitute to air pollution in the studied area.

Concentrations of vanadium in samples of moss obtained from some locations within Port Harcourt ranged from 1.26 ppm (at F6: Onne) to 8.56 ppm (at F21: Dockyard Creek). Mean concentration was recorded as 3.8188 while the calculated standard deviation was 2.5335 .
Vanadium (V) is a bright white ductile metal belonging to group $\mathrm{V}$ of the periodic system of elements. It has an atomic mass of 55 and belongs to the transition metals. Vanadium is mainly used in steel industry for the production of highstrength and low-alloy. Another important application is its use as a heterogeneous catalyst (i.e. for after treatment of vehicle exhaust gasses). Vanadium is known to be present in both crude oil and coal, in widely varying concentrations. (1-1500mg/ $\mathrm{kg}$ ). Vanadium in crude oil is concentrated in the heaviest distillation fractions and can reach very high concentrations in derived fuels such as residual oil and petroleum coke. Vanadium emission comes from anthropogenic and natural sources but the anthropogenic contribution dominates especially in densely populated areas such as Western Europe. Vanadium emissions are mainly particle-bound and especially the submicron particle size fraction can travel over long distances making it relevant for trans-boundary air pollution. Numerous studies have reported acute and chronic respiratory effects due to exposure to vanadium [27]. The neurotoxin effects of vanadium and its potential to induce chronic neurological diseases are not well understood but have been associated with depression and Parkinson's disease. Vanadium is an element of concern for Air Quality and exposure of the human population [27]. Generally, permissible limits of vanadium in air from different regulatory bodies ranged from 0.05 to $0.1 \mu \mathrm{g} / \mathrm{m} 3$ [27]. Therefore, vanadium is not a serious contributor to air pollution in the study areas.

Concentrations of copper in moss samples obtained from the study areas exhibited mean value and standard deviation of $7.136 \mathrm{ppm}$ and 1.5508 respectively. Minimum concentrations of copper were $4.28 \mathrm{ppm}$ while maximum concentrations of 9.87 ppm were observed at F2 (Dockyard Creek). Copper is a very common substance that occurs naturally in the environment and spreads through the environment through natural phenomena. Humans widely use copper for instance it is applied in the industries and in agriculture. The productions of copper in large quantity in the environment have expanded. Copper can be released into the environment by both natural sources and human activities. Most regulatory agencies fix the recommended limit for copper in the air to be $1 \mu \mathrm{g} / \mathrm{m}^{3}$. Therefore, copper does not constitute significantly to air pollution in the studied area.

Zinc ion concentrations ranged from 11.23ppm (at F25: Akpakim House) to 9.8 ppm (at F21: Dockyard Creek). Zinc is an essential nutrient for humans, but excessive amounts (more than twice the recommended daily intake) can be harmful. The primary anthropogenic sources of zinc in the environment (air, water, soil) are related to mining and metallurgic operations involving zinc and use of commercial products containing zinc. There are few data regarding the speciation of zinc released to the atmosphere. Zinc is removed from the air by dry and wet deposition, but zinc particles with small diameters and low densities suspended in the atmosphere travel long distances from emission sources. Zinc has been detected in air, surface 
water, groundwater, and soil; the frequency of detection and the concentrations are greatest near source areas (e.g., hazardous waste sites and industrial areas such as lead smelters). In a survey by the National Air Surveillance Network, the mean concentration of zinc in the air in the United States in 1977-1979 was $0.02-0.16 \mu \mathrm{g} / \mathrm{m}^{3}$ for urban air compared to $0.01-0.05 \mu \mathrm{g} /$ $\mathrm{m}^{3}$ for rural air. Presently, there is no generally acceptable recommended limit for the concentration of zinc ion in the air. However, recommended permissible limits for zinc oxide in fumes and dust are 5 and $15 \mu \mathrm{g} / \mathrm{m}^{3}$. Therefore, the air quality of study areas is not polluted with respect to zinc ion.

Concentrations of nickel ion in mosses obtained from Port Harcourt ranged from 1.10ppm (at F4: Rumuola) to $8.54 \mathrm{ppm}$ (at F19: Calabari Creek). Mean concentration was 3.9036ppm. Nickel may be released to the environment from the stacks of large furnaces used to make alloys or from power plants and trash incinerators. The nickel that comes out of the stacks of power plants attaches to small particles of dust that settle to the ground or are taken out of the air in rain or snow. It usually takes many days for nickel to be removed from the air. If the nickel is attached to very small particles, it can take more than a month to settle out of the air. However, most of the Nickel in the air is known to settle in the soil or enter the surrounding water.
Occupational studies of nickel exposure have not provided dose-specific estimates of risk for individual species, and only rarely total exposure estimates that are comparable between the different plants. The diameter of most nickel in urban air is 0.83 $1.67 \mu \mathrm{m}$, and less than $1 \mu \mathrm{m}$ in $2855 \%$ of particles [28]. Most regulatory bodies fix permissible limit of nickel ion in air to be in the range of 0.1 to $1 \mu \mathrm{g} / \mathrm{m}^{3}$, indicating that the air quality of the studied areas is not polluted with nickel particulates.

Concentrations of iron ion in mosses obtained from the studied areas ranged from $4.13 \mathrm{ppm}$ (at F23: Mile 3 Park) to 7.85ppm (at F21: Dockyard Creek) in Port Harcourt. Mean concentration and standard deviation were 5.6800 \pm 1.2102 . Iron is an element needed by the body, however, results of researches conducted in Mexico on human brain exposed to particulates from iron and steel mining industries revealed that biological magnetite usually forms in tetrahedral or octahedral shapes, but the vast majority of magnetite particles found in this study were instead round nano spheres (like the one below). The researchers detected other unexpected metallic nano particles in the brain samples, too: platinum, nickel, and cobalt. None of these metals occurs naturally in the brain, suggesting an environmental origin. Therefore, excessive concentrations of iron particulates in the atmosphere may be injurious to health.

Table 2: Correlation coefficients for elemental constituents of moss obtained from various locations in Port Harcourt.

\begin{tabular}{|c|c|c|c|c|c|c|c|c|c|c|c|}
\hline & Al & Mg & $\mathrm{Na}$ & $\mathbf{P b}$ & Hg & $\mathrm{Cr}$ & V & $\mathrm{Cu}$ & $\mathrm{Zn}$ & $\mathbf{N i}$ & $\mathbf{F e}$ \\
\hline $\mathrm{Al}$ & 1 & & & & & & & & & & \\
\hline $\mathrm{Mg}$ & 0.3462 & 1 & & & & & & & & & \\
\hline $\mathrm{Na}$ & 0.3721 & 0.1274 & 1 & & & & & & & & \\
\hline $\mathrm{Pb}$ & -0.1652 & -0.1737 & -0.224 & 1 & & & & & & & \\
\hline $\mathrm{Hg}$ & -0.0802 & -0.3392 & -0.4365 & 0.4786 & 1 & & & & & & \\
\hline $\mathrm{Cr}$ & 0.1648 & -0.1369 & -0.2209 & 0.5389 & 0.7893 & 1 & & & & & \\
\hline V & 0.8059 & 0.1696 & 0.3427 & 0.0865 & 0.1565 & 0.5076 & 1 & & & & \\
\hline $\mathrm{Cu}$ & 0.6145 & 0.4634 & 0.2393 & 0.2799 & 0.1153 & 0.3015 & 0.7076 & 1 & & & \\
\hline $\mathrm{Zn}$ & 0.8224 & 0.4347 & 0.2678 & -0.0202 & -0.0135 & 0.3161 & 0.8741 & 0.779 & 1 & & \\
\hline $\mathrm{Ni}$ & 0.6401 & -0.1178 & 0.3771 & 0.0488 & 0.2476 & 0.5152 & 0.8895 & 0.4343 & 0.6689 & 1 & \\
\hline $\mathrm{Fe}$ & 0.7254 & 0.0089 & 0.2971 & 0.1373 & 0.2476 & 0.445 & 0.8976 & 0.7058 & 0.7802 & 0.8724 & 1 \\
\hline
\end{tabular}

Table 2 shows correlation coefficient between metal ions identified in moss samples. Statistical analysis of the results reveals strong positive correlation between $\mathrm{Al} / \mathrm{V}, \mathrm{Al} / \mathrm{Zn}, \mathrm{Al} / \mathrm{Fe}$, $\mathrm{Hg} / \mathrm{Cr}, \mathrm{V} / \mathrm{Cr}, \mathrm{V} / \mathrm{Zn}, \mathrm{V} / \mathrm{Ni}, \mathrm{V} / \mathrm{Fe}, \mathrm{Cu} / \mathrm{Zn}, \mathrm{Cu} / \mathrm{Fe}, \mathrm{Zn} / \mathrm{Fe}$ and $\mathrm{Ni} / \mathrm{Fe}$. Therefore, these concentrations of these pair elements increases or decreases correspondingly. In Ibeno, strong negative correlation existed between $\mathrm{Mg} / \mathrm{Fe}$ and $\mathrm{Hg} / \mathrm{Cu}$ while strong positive correlation existed between $\mathrm{Cr} / \mathrm{V}, \mathrm{Cr} / \mathrm{Ni}, \mathrm{V} / \mathrm{Ni}$ and $\mathrm{Cu} /$ $\mathrm{Ni}$. The negative correlation suggests that as the concentration of one increases, the concentration of the other decreases while the

positive correlation indicates that their concentration increases or decreases correspondingly [29].

\section{Hydrocarbon profile of moss}

GC-FID profile of hydrocarbons in moss obtained from stations 1 to 4 (F1 to F4) were obtained and the results obtained were interpreted and summarized in Table 3-5. Although the concentrations of the various hydrocarbons in station 4 vary, the range of distribution recorded in this station was n-C10 to n-C34. 


\section{Open Access Journal of Toxicology}

Table 3: Relative concentration levels of some hydrocarbons in mosses samples from station 1 in Port Harcourt.

\begin{tabular}{|c|c|c|}
\hline Hydrocarbon & IUPAC name & Relative Concentration (\%) \\
\hline C10 & Decane & 4.38 \\
\hline C11 & Undecane & 1.46 \\
\hline C12 & Dodecane & 1.46 \\
\hline C13 & Tridecane & 2.71 \\
\hline C14 & Tetradecane & 2.71 \\
\hline C15 & Pentadecane & 4.8 \\
\hline C16 & Hexadecane & 2.92 \\
\hline C17 & Heptadecane & 6.47 \\
\hline C18 & Octadecane & 4.18 \\
\hline C19 & Nonadecane & 4.18 \\
\hline $\mathrm{C} 20$ & Eicosane & 7.09 \\
\hline $\mathrm{C} 21$ & Henicosane & 7.09 \\
\hline $\mathrm{C} 22$ & Docosane & 7.72 \\
\hline $\mathrm{C} 23$ & Tricosane & 7.72 \\
\hline $\mathrm{C} 24$ & Tetracosane & 7.72 \\
\hline $\mathrm{C} 25$ & Pentacosane & 4.18 \\
\hline C26 & Hexacosane & 5.84 \\
\hline $\mathrm{C} 27$ & Heptacosane & 4.8 \\
\hline $\mathrm{C} 28$ & Octacosane & 4.38 \\
\hline $\mathrm{C} 29$ & Nonacosane & 2.71 \\
\hline C30 & Tricotane & 1.46 \\
\hline C31 & Hentriacontane & 1.46 \\
\hline C32 & Dotriacontane & 1.46 \\
\hline C33 & Tritriacontane & 1 \\
\hline
\end{tabular}

Table 4: Relative concentration levels of some hydrocarbons in mosses samples from station 2 in Port Harcourt.

\begin{tabular}{|c|c|c|}
\hline Hydrocarbon & IUPAC name & Relative Concentration (\%) \\
\hline $\mathrm{C} 10$ & Decane & 4.61 \\
\hline C11 & Undecane & 3.55 \\
\hline C12 & Dodecane & 4.08 \\
\hline C13 & Tridecane & 5.14 \\
\hline C14 & Tetradecane & 6.03 \\
\hline C15 & Pentadecane & 6.56 \\
\hline C16 & Hexadecane & 6.56 \\
\hline C17 & Heptadecane & 6.56 \\
\hline C18 & Octadecane & 6.56 \\
\hline C19 & Nonadecane & 6.56 \\
\hline $\mathrm{C} 20$ & Eicosane & 6.56 \\
\hline $\mathrm{C} 21$ & Henicosane & 5.49 \\
\hline $\mathrm{C} 22$ & Docosane & 5.49 \\
\hline $\mathrm{C} 23$ & Tricosane & 4.61 \\
\hline $\mathrm{C} 24$ & Tetracosane & 4.61 \\
\hline $\mathrm{C} 25$ & Pentacosane & 3.55 \\
\hline C26 & Hexacosane & 3.01 \\
\hline $\mathrm{C} 27$ & Heptacosane & 2.48 \\
\hline $\mathrm{C} 28$ & Octacosane & 1.95 \\
\hline C29 & Nonacosane & 1.42 \\
\hline C30 & Tricotane & 1.42 \\
\hline C31 & Hentriacontane & 1.42 \\
\hline C32 & Dotriacontane & 0.88 \\
\hline $\mathrm{C} 33$ & Tritriacontane & 0.88 \\
\hline
\end{tabular}

Table 5: Relative concentration levels of some hydrocarbons in mosses samples from station 3 in Port Harcourt.

\begin{tabular}{|c|c|c|}
\hline Hydrocarbon & IUPAC name & Relative concentration (\%) \\
\hline C10 & Decane & 6.92 \\
\hline C11 & Undecane & 6.18 \\
\hline C12 & Dodecane & 7.92 \\
\hline C13 & Tridecane & 8.78 \\
\hline C14 & Tetradecane & 8.29 \\
\hline C15 & Pentadecane & 7.92 \\
\hline C16 & Hexadecane & 7.54 \\
\hline C17 & Heptadecane & 6.68 \\
\hline C18 & Octadecane & 6.18 \\
\hline C19 & Nonadecane & 6.93 \\
\hline C20 & Eicosane & 4.83 \\
\hline C21 & Henicosane & 3.96 \\
\hline C22 & Docosane & 3.58 \\
\hline C23 & Tricosane & 3.09 \\
\hline C24 & Tetracosane & 2.59 \\
\hline C25 & Pentacosane & 2.1 \\
\hline C26 & Hexacosane & \\
\hline
\end{tabular}


In station 1, evidence abound that the presence of UCM, GRO and DRO were much prominent than in other stations. These suggest that past and recent hydrocarbon contaminations by crude oil and by-product of crude oil abound in this station. These can be attributed to the higher levels of industrial activities and off shore production in Port Harcourt, the major activities that may contribute to air pollution are exploration, gas flaring, mobile and stationary engines. In Port Harcourt, other petroleum related activities such as Eleme Petrochemical, Port Harcourt Refinery, Fertilizer plants, etc can adequately escalate the level of air pollution in this location. Station 2 seems to present range of hydrocarbon distribution that can be regarded as a finger print when compare to station 1 . Concentration values were also closely related. This suggests that although the two stations are far away from each other, hydrocarbon contamination is effectively the same. This justify that activities carried out in one location can affects the various locations. Generally in both stations, interesting ranges associated with the presence of UCM, GRO and DRO were established indicating that past and recent contamination is in progress and that hydrocarbon degradation as well as evaporation is ongoing.

The GC-FID of moss obtained from station 3 in Port Harcourt reveal the abundance of $\mathrm{C} 14$ to $\mathrm{C} 20$ and lower concentrations of the lower and higher molecular weight hydrocarbons. Range of hydrocarbon distribution in moss samples obtained from this location ranged from $\mathrm{n}-\mathrm{C} 10$ to $\mathrm{n}-\mathrm{C} 33$. As stated before, the dominant of hydrocarbons species associated with UCM also suggest the existent of recent contamination. The presence of fractions $>$ n-C23 suggest past contamination and the presence of hydrocarbon up to n-C33 suggest that the hydrocarbon contamination is associated with crude oil from algal-microbial pale environment. Hence finally, station 4 reveals the presence of hydrocarbons ranging from n-C10 to n-C26, which largely fall within the UCM range. Hence this location is recently contaminated with crude oil and crude oil by-products. The location is far from the industrial zone of Port Harcourt and yet it is influence by hydrocarbon pollution, suggesting that hydrocarbon pollution may not be localized but could be global.

\section{Conclusion and Recommendation}

From the results and finding of this research, the following conclusions are made,

i. Concentrations of trace metals in Hylocomium splendens (moss) taken from some locations within Port Harcourt are within permissible limits.

ii. Concentration level of hydrocarbons in Hylocomium splendens (moss), in Port Harcourt does not constitute significant air pollution.

iii. Trace metals and hydrocarbon concentrations in Hylocomium splendens obtained from Port Harcourt show spatial geographical distributions. iv. Sources of hydrocarbons and trace metal pollution in Port Harcourt are strongly influence by industrial activities within the area.

v. Although the present levels of hydrocarbon and trace metal concentrations in the atmosphere surrounding Port Harcourt are within safety levels, there is eminent future danger if the discharge of potential gaseous pollutants within the areas is not brought to control.

In view of the above conclusions, it is recommended that future study be conducted on the concentrations levels of paraaromatic hydrocarbons in the area. There is a serious need to correlate air pollution indices with those obtained for aquatic pollution.

\section{References}

1. Tingey DT (1989) Bioindicators in air pollution research- Applications and constraints Biologic Markers of Air-Pollution Stress and Damage in Forests. Washington, DC National Academies Press 73-80.

2. Onianwa PC (2001) Monitoring atmospheric metal pollution: a review of the use of mosses as indicators. Environ Monit Assess 71(1): 13-50.

3. Palmieri F, Neri RBC, Serracca L (1997) Lichens and moss as bioindicators and bioacculators in air +pollution monitoring. J Environ Pathol Toxicol Oncol 16(2-3): 175-190.

4. William EW, Derek B (1978) Terrestrial mosses as bioindicators of $\mathrm{SO}_{2}$ pollution stress synecological analysis and the index of atmospheric purity. Oecologia 35(2): 221-230.

5. Čeburnis D, Šakalys J, Armolaitis K, Valiulis D, Kvietkus K (2002) Instack emissions of heavy metals estimated by moss biomonitoring method and snow-pack analysis. Atmospheric Environment 36(9): 1465 - 1474.

6. Čeburnis D, Šakalys J, Valiulis D, Kvietkus K (2000) Semi-empirical modeling of trace metal deposition close to the point pollution source.

7. Čeburnis D, Rühling ÅK (1999) Extended study of atmospheric heavy metal deposition in Lithuania based on moss analysis. Environmental Monitoring and Assessment 47(2): 135-152.

8. Giordano S, Sorbo S, Adamo P, Basile A, Spagnuolo V, Cobianchi CR (2004) Biodiversity and trace element content of epiphytic bryophytes in urban and extra urban sites of southern Italy. Plant Ecology.170: $1-14$.

9. Figueira R, Sergio C, Sousa AJ (2002) Distribution of trace metals in moss biomonitors and assessment of contamination sources in Portugal. Environmental Pollution 118(1): 153-163.

10. Adamo P, Giordano S, Vingiani S, Cobianchi RC, Violante P (2003) Trace element accumulation by moss and lichen exposed in bags in the city of Naples (Italy). Environ Pollut 122(1): 91-103.

11. Alvarez MA, Estévez AJR, Iglesias BH, Pérez AO, López SD, et al. (2006) Lichen based biomonitoring of air quality in Havana City west side. Journal of Radioanalytical and Nuclear Chemistry 270(1): 63-67.

12. Ares A, Aboal JR, Fernandez JA, Real C, Carballeira A (2009) Use of the terrestrial moss Pseudoscleropodiumpurum to detect sources of small scale contamination by PAHs. Atmospheric Environment 43: 55015509.

13. Azizullah A, Murad W, Muhammad A, Waheed U, Häder D (2013) Gravitactic orientation of Euglena gracilis-A sensitive endpoint for ecotoxicological assessment of water pollutants. Front Environ Sci $1(4): 1-4$. 
14. Buonocore M, Cardellicchio N, Z Di Leo A (2010) Assessment of atmospheric heavy metal deposition in the Taranto urban area using the moss biomonitoring technique and ICP -MS analysis. Special Abstracts/Journal of Biotechnology 150S (2010) S1-S576.

15. Chakraborty Sh, Paraktar GT (2006) Biomonitoring of trace element air pollution using mosses. Aerosol and Air Quality Research 6(3): 247 258

16. Cowden P, Liang T, Aherae J (2015) Mosses as bioindicators of air pollution along an urban agricultural transect in the Credit River watershed, Southern Ontario, Canada. Annali Botanica 5: 63-70.

17. Cucu-Man SM, Steinnes E (2013) Analysis of selected biomonitors to evaluate the suitability for their complementary use in monitoring trace element atmospheric deposition. Environ Monit Assess 185(9): 7775-7791.

18. Anicic M, Frontasyeva MV, Tomas M, Popovic A (2007) Assessment of Atmospheric deposition of heavy metals and other elements in Belgrade using the moss biomonitoring technique and neutron activation analysis. Environmental Monitoring and Assessment 129 207-219.

19. Anicić M, Tasić M, Frontasyeva MV, Tomasević M, Rajsić S, et al (2009) Active moss biomonitoring of trace elements with Sphagnum girgensohnii moss bags in relation to atmospheric bulk deposition in Belgrade Serbia. Environ Pollut 157(2): 673-679.

20. Mendil D, Celix F, Tuzen M, Soylak M (2009) Assessment of trace metals levels in some moss and lichen samples collected from near the motorway in Turkey. J Hazard Mater 166(2-3): 1344-1350.

21. Basile A, Sorbo S, Aprile G, Conte B, Castaldo CR, et al. (2009) Heavy metal deposition in the Italian "triangle of death" determined with the moss Scorpiurum circinatum. Environmental Pollution 157: 22552260 .

22. Bargagli R, Monaci F, Borghini F, Bravi F, Agnorelli C (2002) Mosses and lichens as biomonitors of trace metals. A comparison study on Hypnum cupressiforme and Parmelia caperata in a former mining district in Italy. Environ Pollut 116(2): 279-287.

23. Dmytro B, Alexander B (1974) Air pollution by aluminum compounds resulting from corrosion of air conditioners. Environ Sci Technol 8(8): $752-755$.

24. Petrela J, Camara VM, Kennedy G, Bouyahi B, Zayed J (2001) Health effects of residential exposure to aluminum plant air pollution. Archive of Environmental Health 56(5): 456-460.

25. WHO World Health Organization (2000) Air Quality Guidelines, Chapter 6.12 Vanadium, $2^{\text {nd }}$ (edn.), WHO Regional Office for Europe.

26. Lee RE, Von Lehmden DJ (1973) Trace metal pollution in the environment. Journal of the Air Pollution Control Association 23(10): 853-857.

27. Čeburnis D, Steinnes E, Kvietkus K (1999) Estimation of metal uptake efficiencies from precipitation in mosses in Lithuania. Chemosphere 38(2): 445-455.

28. Foan L, Sablayrolles C, Elustondo D, Lasheras E, Gonzalez L, et al. (2010) Reconstructing historical trends of polycyclic aromatic hydrocarbon deposition in a remote area of Spain using herbariums moss material. Atmospheric Environment 44(26): 3207-3214.

29. Lee Y, Johnson-Green P, Lee EJ (2003) Correlation between environmental conditions and the distribution of mosses exposed to urban air Pollutants. Water Air and Soil Pollution 153(1-4): 293-305.

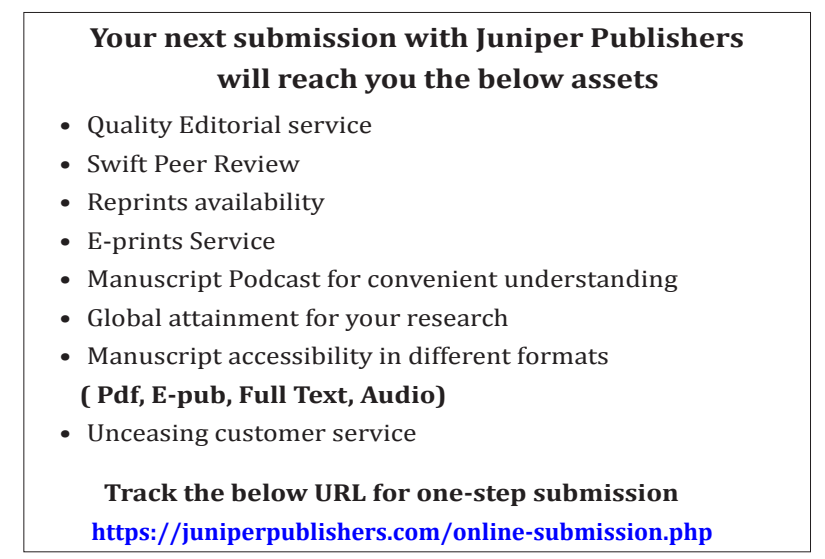

